\title{
The Understandings of Genetics Concepts and Learning Approach of Pre-Service Science Teachers
}

\author{
Bahattin Deniz Altunoğlu \\ Faculty of Education, Kastamonu University, Turkey \\ bdaltunoglu@kastamonu.edu.tr \\ Metin Şeker \\ Student of Graduate Science Institute Kastamonu University, Turkey \\ mtnseker@gmail.com
}

\section{Doi:10.5901/jesr.2015.v5n1s1p61}

\section{Abstract}

\begin{abstract}
Advances in genetics and related technology have significant influence on our life. Recently, one of the most popular scientific and technological advances are related with genetics such as human genome project, genetically modified organism, cloning of organism, gene therapy and genetic background of various illness etc.. With the discoursing of this, society demands clear cut information to evaluate these genetics related issues having ethic and social characteristics. Becoming of evaluations' skills for genetics related controversial issues required sufficient understanding of basic genetic concepts. At this point science education and science teachers take priority for the supplying of scientific literacy which is required for making informed decision about of genetic related controversial issues imposed by daily life. However, some researches indicated that teachers are one of the reasons of students' misconceptions. In this study pre-service science teachers' difficulties of genetics concepts and relationship understanding level and learning approach was investigated with 196 pre-service science teachers, who were studying at Kastamonu University Faculty of Education. Data collection tools were multiple choice Genetics Concepts Test and Learning Approach Questionnaire, four-point Likert type instrument. Data obtained from Genetics Concepts Test were described by means, variance and most frequently false responses were determined to uncover misunderstanding of genetic concepts. Correlation analyses were conducted to examine relationship between pre-service teachers' understanding of genetics concepts and learning orientations.
\end{abstract}

Keywords: genetic concepts, pre-service science teachers, learning approach

\section{Introduction}

Recently, one of the most popular scientific and technological advances are related with genetics such as human genome project, genetically modified organism, cloning of organism, gene therapy and genetic background of various illness etc. These advancements caused by society curiosity and concern (Kılıç \& Sağlam 2014). As experienced in all scientific and technological developments, little information fragments from discussions of scientists and specialists reflected by mass media. For instance genetically modified organism have risks related with health problem and environmental problem but such organism can provide benefits; these controversial opinions expressed by experts (Durrant \& Legge 2005). Society by such controversial topics needs basic knowledge to make meaningful decision which is the best one between lots of options. At this point science education and science teachers take priority for the supplying of scientific literacy which is required for making informed decision about of genetic related controversial issues imposed by daily life, because teachers are an critical link for the general public's understanding and perception of scientific developments (Yates \& Marek 2013; Nehm \& Schonfeld 2007). This mission burden on the teachers that they have the best scientific literacy, however literature shows that teachers play a role by having learning difficulties of students (Sander 1993, Soyibo 1995, Yates \& Marek 2014) and pre-service teachers and teachers have difficulties with understanding of various biology concepts (Bishop \& Anderson 1998, Yip 1998; Tekkaya, Çapa, \& Yılmaz. 2000; Dikmenli, Cardak \& Kiray 2011; Kurt, Ekici, Aksu, \& Aktaş, 2013; Özgür 2013).

Other side understanding of concepts in genetics contributes meaningful learning evolution which is complex and misunderstood areas of biology such as evolution.

Genetics is a basic topic in biology however it is perceived difficult by students and teachers (Johnstone, \& 
Mahmoud, 1980; Bahar, Johnstone \& Hansell, 1999; Knippels et al., 2005). Knippels (2002) determined some difficulties which should be effective in genetic education: the domain-specific terminology, the cytological processes and the abstract nature of the genetics concepts. In addition to the nature of topic, some cognitive factors like reasoning ability and learning orientation have effect on learning of abstract and complex topics. In this scope level of understanding of genetics and effect of learning approach on this situation were aimed with this investigation.

\section{Research Method}

Primary aim of study was investigate understanding of genetics. Additionally the correlation between pre-service science teachers' understanding level of genetics and learning orientation was determined. The design of investigation was descriptive study since main aim of study was uncover and interpret inherent condition of pre-service teachers' understanding of genetics.

\section{Research Group}

Research group of study consisted of 196 pre-service science teachers at the Faculty of Education in Kastamonu University. The average age of pre-service science teachers was 21.2 years (range 18 - 23).

Data collection tools

In the study multiple choice Genetic Concept Test (GCT) and Learning Approach Questionnaire (LAQ) was used to state students' understanding level of genetics concepts and learning orientations.

\section{Genetic Concept Test (GCT)}

GCT was designed to uncover of understanding level of pre-service science teachers about basic concepts of genetics such as DNA, chromosome, gene, genome and cell divisions. Some items of test were designed to determine the understanding level of relationship among these basic concepts. GCT consisted 22 multiple choice type items. For calibration of GCT a pilot study was performed with 125 pre-service science teachers, which were separate from study group. The pilot study of GCT was accomplished by conducting item analysis in which difficulty and discrimination indices of each item were calculated. Item discrimination indices were found to between 0.22 and 0.62 , item difficulty indices were between 0.27 and 0.86 . To assess internal consistency reliability, the Kuder-Richardson 20 (KR-20) formula was used and KR-20 coefficient was found to be 0.68 . These values showed that items functioned in a satisfactory way.

\section{Learning Approach Questionnaire (LAQ)}

The LAQ, which is 22-item, 4-point Likert instrument, was designed to state of individuals' learning approach ranging from meaningful to rote (Cavallo 1996). The instrument has two subscales: Learning Approach QuestionnaireMeaningful (LAQ-M) and the Learning Approach Questionnaire-Rote (LAQ-R). The LAQ-M and the LAQ-R consist of 11 items each. Participants responded to each statement by indicating their agreement, ranging from 4 (strongly agree) to 1 (strongly disagree). High scores for LQA-R indicated a strong tendency toward rote learning and high scores for LQA-M R indicated a strong tendency toward meaningful learning.

The questionnaire was adapted to Turkish by Tekkaya and Yenilmez ( 2006) and Cronbach alpha internal consistency of instrument was calculated by authors $r=.78$ for the LAQ-M and $r=.62$ for LAQ-R. The LAQ was frequently used by Turkish researchers for uncover the effects of cognitive variables on learning of scientific concepts ( Sadi \& Çakıroğlu, 2012; Gürçay 2013; Kılıç \& Sağlam, 2014).

\section{Data Analysis}

The data obtained by GCT and LAQ were described mean and variance. GCT and LAQ mean scores each were tested by one way analysis of variance (ANOVA) and Pearson correlation coefficient was calculated between mean scores of GCT and LAQ. In addition to statistic procedures frequently false answers of participants were determined. 


\section{Results}

The data about pre -service science teachers' understanding of fundamental concepts of genetics was collected by GCT. Mean scores (M) and standard deviation (SD) obtained GCT were displayed by Table 1.

Table 1. GCT mean scores and Standard deviation distribution according to grade level

\begin{tabular}{cccc}
\hline Grade level & $\mathrm{N}$ & $\mathrm{M}$ & $\mathrm{SD}$ \\
\hline Freshmen & 65 & 9,52 & 3,20 \\
Sophomore & 50 & 8,74 & 3,88 \\
Junior & 81 & 11,28 & 3,26 \\
\hline Total & 196 & 10,06 & 3,57 \\
\hline
\end{tabular}

According to Table 1GCT mean scores show increasing trend across the grade level of pre-service science teachers.

One way analysis of variance (ANOVA) was conducted to examine possible differences in participants' GCT scores relative to their grade levels and results displayed by Table 2 .

To examine statistically significance of differences between GCT mean scores according to participants' grade level ANOVA was employed and results displayed by Table 2

Table 2. One way analysis of variance with GCT scores

\begin{tabular}{|c|c|c|c|c|c|}
\hline & Sum of square & $\mathrm{df}$ & Mean Square & $\mathrm{F}$ & $p$ \\
\hline Between groups & 226,573 & 2 & 113,286 & \multirow{3}{*}{9,721} & \multirow{3}{*}{0,000} \\
\hline Within groups & 225,803 & 191 & 11,653 & & \\
\hline Total & 2452,376 & 193 & & & \\
\hline
\end{tabular}

Statistically significant difference between GCT scores of pre-service science teachers according to grade level was determined $[F(2,191)=9.721, p=0.000]$.

LAQ was used to determine the learning approach of participants. This instrument had two subscales; LAQ-R and LAQ-M.

Mean scores (M) and standard deviation (SD) obtained LAQ-R were displayed by Table 3.

Table 3. LAQ-R mean scores and Standard deviation distribution according to grade level

\begin{tabular}{cccc}
\hline Grade level & N & M & SD \\
\hline Freshmen & 65 & 29,25 & 4,68 \\
Sophomore & 50 & 26,90 & 4,59 \\
Junior & 81 & 27,01 & 3,94 \\
\hline Total & 196 & 27,72 & 4,48 \\
\hline
\end{tabular}

According to Table 3 LAQ-R scores display a decreasing trend across the grade level of participants.

One way analysis of variance (ANOVA) was conducted to examine possible differences in participants' LAQ-R scores relative to their grade levels and results displayed by Table 4 .

Table 4. One way analysis of variance with LAQ-R scores

\begin{tabular}{|c|c|c|c|c|c|}
\hline & Sum of square & $d f$ & Mean Square & $\mathrm{F}$ & $p$ \\
\hline Between groups & 225,573 & 2 & 112,787 & \multirow{3}{*}{5,913} & \multirow{3}{*}{0,003} \\
\hline Within groups & 3681,549 & 193 & 19,075 & & \\
\hline Total & 3907,122 & 195 & & & \\
\hline
\end{tabular}

Statistically significant difference between GCT scores of pre-service science teachers according to grade level was determined $[F(2,193)=5.913, p=0.003]$.

Mean scores (M) and standard deviation (SD) obtained LAQ-M were displayed by Table 5. 
Table 5. LAQ-M mean scores and Standard deviation distribution according to grade level

\begin{tabular}{cccc}
\hline Grade level & N & M & SD \\
\hline Freshmen & 65 & 30,91 & 5,89 \\
Sophomore & 50 & 32,04 & 4,39 \\
Junior & 81 & 31,41 & 4,16 \\
\hline Total & 196 & 31,40 & 4,85 \\
\hline
\end{tabular}

According to Table 5 LAQ-M scores were close to each other and total mean score calculated as 31.40 .

One way analysis of variance (ANOVA) was conducted to examine possible differences in participants' LAQ-R scores relative to their grade levels and results displayed by Table 4 .

Table 4. One way analysis of variance with LAQ-M scores

\begin{tabular}{|c|c|c|c|c|c|}
\hline & Sum of square & df & Mean Square & $F$ & $p$ \\
\hline Between groups & 36,236 & 2 & 18,118 & \multirow{3}{*}{0,769} & \multirow{3}{*}{0,465} \\
\hline Within groups & 4546,922 & 193 & 23,559 & & \\
\hline Total & 4583,158 & 195 & & & \\
\hline
\end{tabular}

There were no statistically significant difference between LAQ-M scores of pre-service science teachers according to grade level $[F(2,193)=0.769, p=0.465]$.

The correlation coefficients were calculated to determine possible relations between participants' understanding of genetics concepts, reasoning ability and learning approaches, and the results of this correlation matrix are presented in Table 6.

Table 6. Correlation coefficients between GCT and LAQ subscales

\begin{tabular}{cccc}
\hline & GCT & LAQ-R & LAQ-M \\
\hline GCT & 1 & $-0,044^{*}$ &, $182^{*}$ \\
LAQ-R & $-0,044^{*}$ & 1 & 0,068 \\
LAQ-M & $0,182^{*}$ & 0,068 & 1 \\
\hline
\end{tabular}

GCT: Genetic Concept Test scores

LAQ-R:=Rote Learning Approach Questionnaire scores

LAQ-M: Meaningful Learning Approach Questionnaire scores

Significant weak correlations were found between GCT and LAQ-M $(r=.182 ; p<.05)$ also between TGCT and LAQ-R $(r=$ $.044 ; p<.05)$. So it can be allege that participants higher level understanding genetics concepts have prefer meaningful learning approach, however it must be considered low level of correlation coefficients.

Responses of teacher candidates for GCT were analyzed so frequently emerged misunderstandings of teacher candidates were detected. In Table 7 detected misunderstandings were displayed.

Table 7. Frequently encountered misunderstandings of pre-service science teachers

- Genetic information about a protein molecule transmitted from one generation to the next by tRNA nucleotide sequences

- Genetic diversity between organisms emerged due to replication

- After cell division disappeared parent cell

- Spindle fiber originate from chromosomes

- Gene genome concept confusion

- The gene for eye color is located in the iris of the eye

\section{Discussion}

The results of the study revealed that science teacher candidates' understandings' level is quite low. However junior teacher candidates have highest GCT scores but their mean score can reach only half point of the maximum test point. The analysis of the false responses showed that teacher candidates have some misunderstandings which have students 
of primary and secondary school. For instance Saka et al. (2006) have determined that $9^{\text {th }}$ and $11^{\text {th }}$ graders had confusion about chromatin and spindle fiber. Science teachers candidates have misunderstanding of concepts related to cell division. These findings are compatible with the findings of Flores et al. (2003).

One of the reasons for difficulty of genetics concepts is unfamiliarity of students with the definitions of the genetics related terms because terms look and sound very similar, e.g. transcription, translation, chromosome and chromatide (Bahar et al, 1999). But this explanation seem not suitable for science teacher candidates because in science teacher training program there are two semester general biology and one semester genetics courses, so teacher candidates should be familiar with such concepts. In this case should be learning orientation of teacher candidates more adequate explanation for low understanding level of genetics concepts. In this study a positive but weak correlation between understanding level of genetics concepts and level of tendency of meaningful learning approach. It is expected results since abstract characteristic of concepts of genetics is commonly expressed reason for the learning difficulty (Saka et al. 2006; Yenilmez 2011; Dikmenli et al. 2011, Kılıç \& Sağlam 2014). The abstractness of genetic concepts makes meaningful learning approach indispensable by preventing from getting misunderstanding. In contrast to this many students' learning approach display rote learning tendency and students don't construct the relationship between concepts (Cavallo \& Schafer, 1994).

It is not surprising that science teacher candidates have decreasing preferences for rote learning approach, increase their grade level, since teacher training programs, in which there are lectures about leaning theories, learning strategies etc. instructed, have positive effect on learning approach positively.

\section{References}

Bahar, M., Johnstone, A. H. \&. Hansell, M. H (1999) Revisiting learning difficulties in biology, Journal of Biological Education, 33(2), 84-86,

Bishop, B. A, \& Anderson, CW. (1990). Student conceptions of natural selection and its role in evolution. Journal of Research in Science Teaching, 27, 415-427.

Cavallo, A. M. L. (1996). Meaningful learning, reasoning ability, and students' understanding and problem solving of topics in genetics. Journal of Research in Science Teaching, 33(6), 625-656

Cavallo, A.M.L., \& Schafer, L.E. (1994). Relationships between students' meaningful learning orientation and their understanding of genetics topics. Journal of Research in Science Teaching, 31, 393-418.

Kılıç, D. \& Sağlam N. (2014) Students'understanding of genetics concepts: the effect of reasoning ability and learning approaches, Journal of Biological Education, 48:2, 63-70

Dikmenli, M., Cardak, O., \& Kiray, S. A. (2011). Science Student Teachers' Ideas about the 'Gene'Concept. Procedia-Social and Behavioral Sciences, 15, 2609-2613.

Din Yan Yip (1998) Teachers' misconceptions of the circulatory system, Journal of Biological Education, 32:3, 207-215,

Durant, R. F., \& Legge, J. S. (2005). Public Opinion, Risk Perceptions, and Genetically Modified Food Regulatory Policy Reassessing the Calculus of Dissent among European Citizens. European Union Politics, 6(2), 181-200.

Flores F, Tovar M, \& Gallegos L (2003). Representation of the cell and its processes in high school students: An integrated view. International Journal of Science Education 25(2): 269-286

Johnstone, A. H. \& Mahmoud, N. A. (1980). Isolating topics of high perceived difficulty in school biology. Journal of Biological Education, 14 (2), 164-166

Knippels, M. C. P., Waarlo, A. J., \& Boersma, K. T. (2005). Design criteria for learning and teaching genetics. Journal of Biological Education, 39(3), 108-112.

Kurt, H., Ekıcı, G., Aksu, Ö., \& Aktaş, M. (2013). The most important concept of transport and circulatory systems: Turkish biology student teachers' cognitive structure. Educational Research and Reviews, 8(17), 1574-1593.

Nehm, R. H., \& Schonfeld, I. S. (2007). Does increasing biology teacher knowledge of evolution and the nature of science lead to greater preference for the teaching of evolution in schools?. Journal of Science Teacher Education,18(5), 699-723.

Ozgur, S. (2013). The Persistence of Misconceptions about the Human Blood Circulatory System among Students in Different Grade Levels. International Journal of Environmental and Science Education, 8(2), 255-268.

Saka Saka A., Cerrah, L., Akdeniz, A.R. ve Ayas, A. (2006). A cross-age study of the understanding of three genetic concepts: How do they Image the gene, dna and chromosome? Journal of Science Education and Technology, 15(2), 192-202

Sander, M. (1993). Erroneous ideas about respiration: The teacher factor, Journal of Research in Science Teaching, 30, 919-934,

Soyibo, K. (1995). A review of some sources of students' misconceptions in biology. Singapore Journal of Education 15( 2), 1-11

Tekkaya, C. \& Yenizmez, A. (2006). Relationships among measures of learning orientation, reasoning ability, and conceptual understanding of photosynthesis and respiration in plants for grade 8 males and females. Journal of Elementary Science Education, Vol. 18(1), 1-14

Tekkaya, C., Çapa, Y., \& Yılmaz, Ö. (2000). Biyoloji öğretmen adaylarının genel biyoloji konularındaki kavram yanılgıları. Hacettepe Üniversitesi Eğitim Fakültesi Dergisi, 18(18). 
Yakışan M. (2013). The alternative conceptions of pre-service teachers concerning the status of organelles during cell division Journal of Baltic Science Education, Vol. 12, No. 6, 2013

Yates, T. B., \& Marek, E. A. (2013). Is Oklahoma really OK? A regional study of the prevalence of biological evolution-related misconceptions held by introductory biology teachers. Evolution: Education and Outreach, 6(1), 1-20.

Yates, T. B., \& Marek, E. A. (2014). Teachers teaching misconceptions: a study of factors contributing to high school biology students' acquisition of biological evolution-related misconceptions. Evolution: Education and Outreach, 7(1), 7.

Knippels M C P J (2002) Coping with the abstract and complex nature of genetics in biology education. The yo-yo learning and teaching strategy. Utrecht: CD-ß Press [http://dspace.library.uu.nl//bitstream/handle/1874/219/full.pdf?sequence=2] 